International Journal of

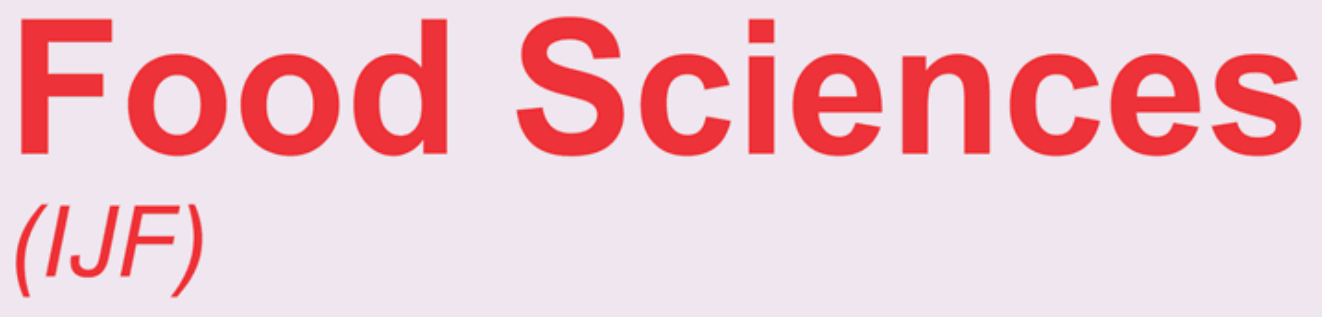

Characterization and Antibiotic profiles of Lactic Acid Bacteria isolated from "Tchoukou" traditional milk cheeses produced in the Zinder region of Niger Republic, West Africa.

Mahamadou Rabiou Moudi Aboubacar, Prof. Willis Owino and Dr. Kevin Mbogo 


\title{
Characterization and Antibiotic profiles of Lactic Acid Bacteria isolated from "Tchoukou" traditional milk cheeses produced in the Zinder region of Niger Republic, West Africa.
}

\author{
$1^{*}$ Mahamadou Rabiou Moudi Aboubacar \\ MSc. Student, Department of Molecular Biology and Biotechnology, Institute of Basic \\ Sciences, Technology and Innovation, Pan African University (PAUSTI), Nairobi, Kenya.

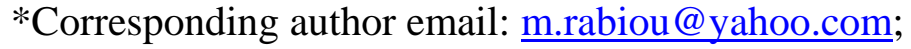 \\ ${ }^{2}$ Prof. Willis Owino \\ Lecturer, Department of Food Sciences and Technology, Jomo Kenyatta University of \\ Agriculture and Technology (JKUAT), Nairobi, Kenya. \\ ${ }^{3}$ Dr. Kevin Mbogo \\ Lecturer, Department of Biochemistry, Jomo Kenyatta University of Agriculture and \\ Technology (JKUAT), Nairobi, Kenya.
}

\begin{abstract}
Purpose: The current study's aim is to identify Lactic Acid Bacteria (LAB) isolated from “ Tchoukou" cheeses made using cow, camel, and goat milk sampled from Zinder region of Niger Republic.

Methodology: Nine samples were collected aseptically from cheesemakers in Zinder Region and the isolation of LAB isolates was carried out using selective media. The isolates were identified based on their phenotypic, biochemical and genotypic characteristics.

Findings: A total of 13 strains of Lactic Acid Bacteria (LAB) were isolated and morphologically and biochemically characterized. Cell morphology analysis identified 12 isolates as rods shaped while 1 isolate was cocci. All isolates were gram positive, Triple Sugar Ion Agar tests (TSIA) positive, and tested negative for catalase. The isolates were also found to be able to grow in a temperature range between 15 and $45 \mathrm{C}$.. The isolates' $16 \mathrm{~S}$ rRNA gene was amplified using bacterial universal primers $27 \mathrm{~F}$ and $1492 \mathrm{R}$. Based on $16 \mathrm{~S}$ rRNA gene analyses, the 13 LAB isolates were grouped into the genera Lactobacillus, and Weissella, traditionally known to occur in raw milk and milk products. The genus Lactobacillus was dominant with $76.92 \%$ of the LAB isolated. Most of the isolated strains were susceptible to eight antibiotics. Therefore, 5 (38.46\%), 3(23.08\%), and $4(30.77 \%)$ isolates showed resistance respectively against Kanamycin, Streptomycin, and CoTrimoxazole. One same isolate $(7.69 \%)$ was discovered resistant to Sulphamethoxazole and Ampicillin.
\end{abstract}

Unique contribution to theory, practice and policy: this study was performed to characterize the LAB isolates found in homemade cheeses that could serve as the potential source for the industries and commercial applications.

Key words: Tchoukou, Lactic Acid Bacteria, morphological and biochemical characteristics, $16 S$ rRNA. Niger Republic. 


\subsection{INTRODUCTION}

Tchoukou is a typical Niger hard cheese prepared from raw milk from cows, goats, and camels. Tchoukou is a milk form used to preserve milk during the dry winter season. It is often created by drying in the sun, which allows it to dry fast without becoming acidic due to microbic flora. Fermented dairy foods are widely consumed all over the world, and demand has risen dramatically in recent years, with market trends indicating that this trend will continue [1]. The popularity of fermented dairy products among consumers is growing due to their nutritional and health benefits, as their influence on the bacterial flora of the gut improves digestion [2]. Cheese is generally defined as a product with a whey protein to casein ratio equal to or less than that of milk [3]. It is the generic name for a set of fermented milk-based food items that include a diverse microbial community (microbiota) that changes over time and varies depending on the kind of cheese, starter and adjunct cultures used [4]. These microbes are important in defining the final product's flavor, quality, and safety. The considerable interspecies variability in milk composition from which the cheese is generated, which can be from cows, camels, goats, or sheep [5], is another reason of diversity in cheese qualities.

Several cheese components are derived from the metabolic action of lactic acid bacteria (LAB), which play an essential part in the cheese-making process and assist to improve the texture and flavor of the finished product. Lactic acid bacteria hydrolyze lactose during fermentation, producing large levels of lactic acid and other organic acids [6].

According to the literature review, isolation and characterization of Lactic Acid Bacteria (LAB) from cow's milk, camel's and goat's milk cheese in the Republic of Niger is yet to be accomplished and thus necessitates these findings.

The objective of this research was to isolate $\mathrm{LAB}$ from traditional cheeses produced from goats' milk, cows' milk and camels' milk to identify those microorganisms based on the phenotypical, biochemical, and molecular characteristics.

\subsection{MATERIALS AND METHODS}

\section{Sampling and isolation of LAB}

Three types of cheeses that were sourced from the milk of goat, cow, and camel were sampled and collected under sterilized conditions from different cheesemakers in the region of Zinder in Niger Republic, West Africa. The purposive sampling method was used due to the sample size being investigated was quite small. Therefore, there were nine samples of cheeses utilized in this study whereby three from each of the three sources mentioned above. All the samples, in their dried state, were covered with aluminum foil and transported from Niger Republic to Kenya.

The samples were crushed into fine powder and $1 \mathrm{~g}$ of each sample was diluted in $9 \mathrm{ml}$ quarter-strength Ringer's solution and vortexed to extract the characteristic LAB associated with dried cheese. $10 \mu \mathrm{l}$ aliquots were spread onto prepared De Man, Rogosa, and Sharpe Agar (MRS agar, M641) and M17 (M929) agar plates. Plates were incubated at $30^{\circ} \mathrm{C}$ for 2448 hours under aerobic conditions according to the method described by Stoll et al., [7] with a slight modification. Colonies were chosen at random from the highest dilution agar plates for further analysis. The strains were then streaked to verify purity after being cultivated aerobically in MRS broth at $30^{\circ} \mathrm{C}$ Ibinabo, et al., [8]. All of the media was acquired through 
Himedia (Mumbai, India). The isolates' stock cultures were kept at $-80^{\circ} \mathrm{C}$ in MRS broth with $20 \%$ glycerol according to the method reported by Abdou et al., [9]. The isolates' morphological and biochemical characteristics were examined, and their identification was verified by $16 \mathrm{~S}$ rRNA gene sequencing.

\subsection{Phenotypic characterization}

The colony form was noticed after establishing a pure culture in a petri dish. Visual observations included shape, colour, edges, and the elevation of bacterial colonies were performed with slightly modified method described by Ismail et al., [9]. The phase-contrast microscopy at 100x magnification was used to identify phenotypically Lactic acid bacteria (Shimadzu CX41, Japan), as well as standard tests such as catalase activity, gas generation from glucose in MRS broth, and growth at various temperatures $\left(15\right.$ and $\left.45^{\circ} \mathrm{C}\right)$.

\subsubsection{Determination of cell morphology and Gram status}

Overnight cultures were placed on microscopic slides and observed under a 100x magnification light microscope and then $3 \% \mathrm{KOH}$ was used to assess Gram status as described by Mulaw et al., [10] slightly modified. For the catalase test, as stated by Mulaw et al., [10] overnight cultures were placed on a tiny glass slide and two drops of 3 percent hydrogen peroxide were added and properly blended. A catalase test that is positive results in the production of gas bubbles. indicating that the test bacteria is generating catalase enzyme. A negative catalase test is indicated by the absence of gas bubbles.

\subsubsection{Growth at different temperatures}

Bacilli are typically categorized using growth temperatures between 15 and $45^{\circ} \mathrm{C}$. MRS broth was used to determine growth at various temperatures. $50 \mu \mathrm{l}$ of overnight cultures was inoculated into $9 \mathrm{ml}$ test medium, incubated at 15 and $45^{\circ} \mathrm{C}$, and colour and growth were monitored for five days times. A negative control was a $9 \mathrm{ml}$ test tube containing broth but with no LAB cultures Ibinabo et al., [11].

\subsection{Lactic Acid Bacteria under biochemical tests}

\section{Gas generation from glucose fermentation}

This test was designed to determine if LAB isolates were homofermentative or heterofermentative. Inverted Durham tubes with 1 percent glucose were used to monitor Carbon (IV) oxide (CO2) generation from glucose in modified MRS broth. Separately, 50 $\mu 1$ of LAB culture was put to $9 \mathrm{ml}$ MRS broth in separate tubes containing 1 percent glucose and inverted Durham tubes. The test tubes were then incubated at $30^{\circ} \mathrm{C}$ for 5 days. Gas bubbles emerged in Durham tubes over the course of five days, showing that the isolates produced CO2 via glucose fermentation as described by [10].

\section{Growth test on different concentrations of salt}

One colony of bacteria was injected into the de Mann Rogosa Sharpe broth (MRS broth) medium at $5 \%, 6.5 \%$, and $10 \% \mathrm{NaCl}$ concentrations. The cultures were subsequently incubated at $37^{\circ} \mathrm{C}$ for one week. The sediment formation in the medium showed the growth of the bacterium Ismail et al., [9]. 


\section{Triple Sugar Iron Agar (TSIA) tests}

The TSIA test was used to determine if bacteria could ferment glucose, lactose, or sucrose. The objective of this experiment was to find out if a particular isolated bacterium could digest glucose, lactose, and sucrose as applied in research by Ismail et al., [9].

\subsection{Antibiotic susceptibility tests}

Eight antibiotic discs in a form of one ring were tested against the LAB isolates. To assess the antibiotic susceptibility against the isolates, spread plate technique was used to spread sample evenly onto the prepared media (MRS Agar) plates. This method is most often applied for microbial analysis of food or any related sample. Thus, after the inoculated plates were dried, a disc containing 8 different antibiotics including Gentamicin (Gen) Sulphamethoxazole (SX); Chloramphenicol (C) Ampicillin (AMP); Tetracycline (TE); Co-Trimoxazole (COT) Streptomycin (K); Kanamycin (K) were aseptically applied onto them. The rings were deposited in the middle of the plate using sterile forceps (F150S, U.S.A). After the accomplishment of rings deposit, all the inoculated plates were incubated immediately at $37^{\circ} \mathrm{C}$ and examined after 48 hours (Figure 1). The experiment was performed in duplicate. The zones showing complete inhibition were measured using ruler and diameters recorded in millimeter (Table 2). The initial diameter of each antibiotic disc was $7 \mathrm{~mm}$.

\subsection{Genotypic Identification}

Genomic bacterial DNA was isolated from overnight cell cultures grown in MRS broth using AddPrep Bacterial Genomic DNA extraction Kit (AddBio Inc, Korea) according to the manufacturer's instructions. The DNA purity and concentration were measured using a NanoDrop spectrophotometer (PCRmax Lambda, Staffordshire, U. K), and DNA quality was verified using a 1 percent agarose gel electrophoresis. According to the method of Ibinabo et al.,[11] PCR amplification of 16S rRNA gene for presumptive LAB strains was carried out using bacterial universal primers 27 F:5-AGA GTT TGA TCC TGG CTC AG-3 and 1492 R:5-GGT TAC CTT GTT ACG ACT T-3. PCR was carried out in a 50 $\mu 1$ reaction comprising $25 \mu$ One Taq ${ }^{\circledR} 2 X$ Master Mix with standard buffer (New England Biolabs, (M0482S)), 1 $\mu \mathrm{l}$ forward primer, $1 \mu \mathrm{l}$ reverse primer, and 201 RNase free water (BioConcept, Cat.N0:307F04-1, Switzerland). The mixture was distributed into $47 \mu \mathrm{l}$ in a sterile PCR tube, and $3 \mu \mathrm{l}$ of gDNA was added and utilized as a template. The amplified gene fragment was subjected to the following conditions: initial denaturation of the target $\mathrm{DNA}$ at $94^{\circ} \mathrm{C}$ for 1 minute, followed by 30 cycles at $94^{\circ} \mathrm{C}$ for 30 seconds, primer annealing at $52^{\circ} \mathrm{C}$ for 30 seconds, and primer extension at $68^{\circ} \mathrm{C}$ for 5 minutes. The PCR was terminated with a 10 minutes elongation at $68^{\circ} \mathrm{C}$ followed by a 4 minutes cooling period. The reactions were performed in a thermal cycler (ProFlex PCR systems). Electrophoresis using 1\% (w/v) of agarose gel stained with Gel Red and observed using the Uvitec Cambridge gel documentation system (Uvitec, UK) confirmed the size of the PCR products for the 16S rRNA gene. According to the manufacturer guidelines, PCR products were purified by using the QIAquick PCR purification kit (Qiagen, Germany). The Gene RulerTM 1 kb plus DNA Ladder was the molecular marker utilized (Thermo Fisher Scientific, US). At Human Genomics Macrogen Europe (Macrogen Europe B.V, Amsterdam, Netherlands), the purified amplicons were Sanger sequenced. 


\section{Phylogenetic analysis}

The 16S rRNA gene sequences of the LAB isolates were checked for quality and edited using BioEdit Sequence Alignment Editor 7.2.5.0 Software package (https://bioedit.software.informer.com/download/). They were then compared to standard sequences of bacteria lineages in the public nucleotide sequence databases of the National Centre for Biotechnology Information (NCBI) using nucleotide blast (https://blast.ncbi.nlm.nih.gov/Blast.cgi) to discover closely related bacterial 16S rRNA gene sequences (Table 2).

\section{Statistical analysis}

Using two-way ANOVA, SPSS statistics version 25, (https://www.updatestar.com/en/directdownload/ibm-spss-statistics/2321346 ), the zone of inhibition findings were represented as the mean and standard deviation of duplicate experiments.

\subsection{RESULTS AND DISCUSSION}

\subsection{Results}

\subsubsection{Morphological and biochemical properties of the isolates}

All isolates were identified based on their physical and biochemical properties (Table 1), as well as their capacity to grow at salt concentrations of $5 \%$ and $6.5 \% \mathrm{NaCl}$. Only five isolates were shown to be viable at $10 \% \mathrm{NaCl}$ concentration. When isolates were screened for their capacity to grow at $15^{\circ} \mathrm{C}$ and $45^{\circ} \mathrm{C}$, it was revealed that all isolates could grow at $15^{\circ} \mathrm{C}$, with only eight isolates growing at $45^{\circ} \mathrm{C}$. Ten of the thirteen isolates produced gas from glucose.

Table 1: Colony morphologies and biochemical characteristics of lactic acid bacteria strains

\begin{tabular}{|c|c|c|c|c|c|c|c|c|}
\hline Isolates ID & Gram stain & Shape & КОН & Form & Catalase & $15^{\circ} \mathrm{C} / 45^{\circ} \mathrm{C}$ & Gas & TSIA \\
\hline ZC1 & + & rods & - & circular & - & $+/-$ & + & + \\
\hline $\mathrm{ZC2}$ & + & rods & - & circular & - & $+/-$ & - & + \\
\hline ZC3 & + & rods & - & circular & - & $+/+$ & + & + \\
\hline ZC4 & + & rods & - & circular & - & $+/-$ & - & + \\
\hline ZCa1 & + & rods & - & circular & - & $+/+$ & + & + \\
\hline $\mathrm{ZCa2}$ & + & rods & - & circular & - & $+/+$ & + & + \\
\hline ZCa3 & + & rods & - & circular & - & $+/+$ & + & + \\
\hline ZCa4 & + & rods & - & circular & - & $+/+$ & + & + \\
\hline ZG1 & + & cocci & - & circular & - & $+/+$ & + & + \\
\hline ZG2 & + & rods & - & circular & - & $+/+$ & + & + \\
\hline ZG3 & + & rods & - & circular & - & $+/+$ & + & + \\
\hline ZG4 & + & rods & - & circular & - & $+/-$ & - & + \\
\hline
\end{tabular}


International Journal of Food Sciences

2789-7680 (online)

Vol. 4, Issue 1, No. 3, pp 30 - 41, 2021

www.iprjb.org

\begin{tabular}{|c|c|c|c|c|c|c|c|c|}
\hline $\begin{array}{l}\text { Isol } \\
\text { ates }\end{array}$ & $\begin{array}{l}\text { Genta } \\
\text { micin }\end{array}$ & $\begin{array}{l}\text { Sulphamet } \\
\text { hoxazole }\end{array}$ & $\begin{array}{l}\text { Chloramp } \\
\text { henicol }\end{array}$ & $\begin{array}{l}\text { Ampi } \\
\text { cillin }\end{array}$ & $\begin{array}{l}\text { Tetrac } \\
\text { ycline }\end{array}$ & $\begin{array}{l}\text { C0- } \\
\text { Trimoxa } \\
\text { zole }\end{array}$ & $\begin{array}{l}\text { Strepto } \\
\text { mycin }\end{array}$ & $\begin{array}{l}\text { Kana } \\
\text { mycin }\end{array}$ \\
\hline ZG & $30.5 \pm 2$ & $24.6 \pm 0.85$ & $21.4 \pm 0.8$ & 9.45 & 26. & $8.5 \pm 2.12$ & $20.75 \pm 1$ & $7.8 \pm 1$ \\
\hline 1 & .12 & & & \pm 0.78 & 1.91 & & .77 & 13 \\
\hline ZG & $27.65 \pm$ & $25.5 \pm 0.71$ & $33.3 \pm 0.99$ & $29 \pm 1$ & $29.7 \pm 3$ & $7 \pm 0.00$ & $7.75 \pm 0$ & $7.55 \pm 0$ \\
\hline 2 & 0.49 & & & 41 & & & & .78 \\
\hline $\mathbf{Z G}$ & $9.5 \pm 0$. & $23.5 \pm 0.71$ & $24.7 \pm 1.84$ & $21.9 \pm$ & $30.5 \pm 2$ & $7.75 \pm 1.06$ & $7 \pm 0.00$ & $11.5 \pm 2$ \\
\hline 3 & 71 & & & 2.97 & 12 & & & .12 \\
\hline ZG & $20.6 \pm 1$ & $9.85 \pm 4.03$ & $23.65 \pm 3.3$ & 23.45 & $28.9 \pm 1$ & $21.35 \pm 3.7$ & $9 \pm 2.83$ & \pm 1.41 \\
\hline 4 & .98 & & 2 & \pm 0.78 & 56 & 5 & & \\
\hline ZG & $27.5 \pm 0$ & $8.8 \pm 2.55$ & $27.7 \pm 3,25$ & $28.5 \pm$ & $31.85 \pm$ & $8.75 \pm 2.47$ & $9.5 \pm 3.5$ & $7.65 \pm 0$ \\
\hline 5 & .71 & & & 2.12 & 0.21 & & 4 & .49 \\
\hline $\mathbf{Z C a}$ & $14.25 \pm$ & $23.25 \pm 1.77$ & $22.9 \pm 1.56$ & 37.25 & $26.4 \pm 2$ & $19.25 \pm 1.0$ & $11.25 \pm 1$ & $9.7 \pm 3$. \\
\hline 1 & 1.06 & & & \pm 1.06 & 26 & 6 & .06 & 82 \\
\hline $\mathbf{Z C a}$ & $17.15 \pm$ & $32.75 \pm 0.96$ & $31.35 \pm 0.9$ & $30.5 \pm$ & $26.3 \pm 2$ & $27.4 \pm 0.85$ & $13.25 \pm 1$ & $8 \pm 1.41$ \\
\hline 2 & 1.20 & & 2 & 0.71 & 40 & & .06 & \\
\hline $\mathbf{Z C a}$ & $17.5 \pm 0$ & $25.65 \pm 0.49$ & $24.35 \pm 2.3$ & 39.75 & $27 \pm 1.4$ & $18.5 \pm 2.12$ & $14.85 \pm 0$ & $7.5 \pm 0$. \\
\hline 3 & .71 & & 3 & \pm 1.18 & 1 & & .21 & 71 \\
\hline $\mathbf{Z C a}$ & $16.25 \pm$ & $25.5 \pm 0.71$ & $22.8 \pm 1.70$ & 29.25 & $25.5 \pm 2$ & $20.4 \pm 2.26$ & $14.5 \pm 0$ & $7.95 \pm 0$ \\
\hline 4 & 1.06 & & & \pm 1.06 & 12 & & 71 & .07 \\
\hline ZC1 & $\begin{array}{c}16.5 \pm 9 \\
10\end{array}$ & $10 \pm 4.24$ & $8.5 \pm 2.12$ & $9.75 \pm$ & $7.5 \pm 0.7$ & $7.25 \pm 0.35$ & $7.5 \pm 0.7$ & $8 \pm 1.41$ \\
\hline $\mathrm{ZC2}$ & $\begin{array}{c}13.9 \pm 0 \\
.14\end{array}$ & $7.25 \pm 0.35$ & $11 \pm 1.41$ & $\begin{array}{c}7.5 \pm 0 . \\
71\end{array}$ & $\begin{array}{c}27.25 \pm \\
1.06\end{array}$ & $9.3 \pm 0.99$ & $\begin{array}{c}9.05 \pm 0 \\
49\end{array}$ & $\begin{array}{c}10.35 \pm \\
0.92\end{array}$ \\
\hline ZC3 & $\begin{array}{c}15.8 \pm 0 \\
.28\end{array}$ & $30.75 \pm 1.06$ & $7.65 \pm 0.92$ & $\begin{array}{l}27.45 \\
\pm 0.78\end{array}$ & $\begin{array}{c}29.6 \pm 3 \\
39\end{array}$ & $8.15 \pm 1.63$ & $\begin{array}{c}8.5 \pm 2.1 \\
2\end{array}$ & $\begin{array}{c}7.9 \pm 2 . \\
27\end{array}$ \\
\hline ZC4 & $\begin{array}{c}13.6 \pm 0 \\
.57\end{array}$ & $8.9 \pm 2.69$ & $\begin{array}{c}35.75 \pm 0.3 \\
5\end{array}$ & $\begin{array}{c}36.5 \pm \\
2.12\end{array}$ & $\begin{array}{c}25.8 \pm 3 \\
11\end{array}$ & $9.35 \pm 3.32$ & $\begin{array}{c}8.45 \pm 2 . \\
05\end{array}$ & $\begin{array}{c}8.7 \pm 2 . \\
40\end{array}$ \\
\hline
\end{tabular}

\subsubsection{Molecular identification of the isolates}

Prior to sequencing, PCR amplicons were obtained and prepared for sequencing (Figure 2). The BLASTn search was used to compare isolates, which revealed 94 to $100 \%$ identity similarity. (Table 3). Based on the BLASTn search performed against the GenBank (Figure 2), the following ten isolates including ZC1 (KP889230.1), ZC2 (KJ784539.1), ZC3 (MG754569.1), ZC4 (MF357249.1), ZCa1 (KX538919.1), ZCa2 (MF369878.1), ZCa3 (KM495896.1), ZCa4 (KR135828.1), ZG4 (EU637399.1) and ZG5 KM4958.1) were found to belong to the genus of Lactobacillus. And only three isolates, ZG1 (HQ009757.1), ZG2 (KX156221.1), and ZG3 (KP137384.1) were affiliated with Weisella cibaria. 


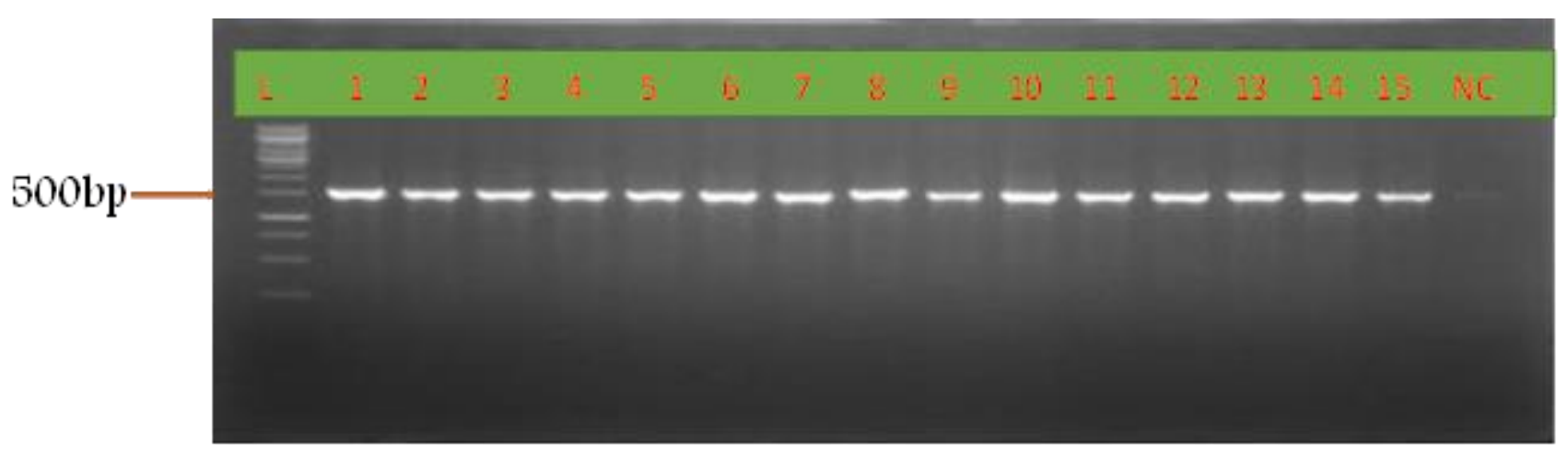

$\boldsymbol{L}=1 \mathrm{~kb}$ DNA Ladder, $\mathrm{NC}=$ negative control, red number $=$ simple serial numbers

Figure 2: PCR amplicons of some amplified bacterial DNA.

Table 3: molecular identities of LAB strains

\begin{tabular}{|c|c|c|c|c|}
\hline $\begin{array}{l}\text { S/N } \\
\text { ID }\end{array}$ & Isolate & Closest relative & $\begin{array}{l}\text { Accession } \\
\text { number }\end{array}$ & $\%$ Identity \\
\hline 1 & ZC1 & Lactobacillus plantarum strain FJ005 & KP889230.1 & 100 \\
\hline 2 & $\mathrm{ZC2}$ & Lactobacillus plantarum. SMG131 & KJ784539.1 & 97 \\
\hline 3 & ZC3 & $\begin{array}{l}\text { Lactobacillus } \quad \text { plantarum } \quad \text { strain } \\
\text { Sourdough_K3 }\end{array}$ & MG754569.1 & 99 \\
\hline 4 & $\mathrm{ZC4}$ & $\begin{array}{l}\text { Lactobacillus paraplantarum strain } \\
\text { CAU4459 }\end{array}$ & MF357249.1 & 100 \\
\hline 5 & ZCa1 & Lactobacillus plantarum strain LP1-4 & KX538919.1 & 100 \\
\hline 6 & $\mathbf{Z C a 2}$ & $\begin{array}{l}\text { Lactobacillus plantarum } \quad \text { strain } \\
\text { CAU: } 226\end{array}$ & MF369878.1 & 99 \\
\hline 7 & ZCa3 & Lactobacillus plantarum strain gp112 & KM495896.1 & 98 \\
\hline 8 & ZCa4 & Lactobacillus plantarum. PP3 & KR135828.1 & 97 \\
\hline 9 & ZG1 & Weissella cibaria strain HN79 & HQ009757.1 & 100 \\
\hline 10 & ZG2 & Weissella cibaria strain BPLP4 & KX156221.1 & 98 \\
\hline 11 & ZG3 & Weissella cibaria strain AT22 & KP137384.1 & 98 \\
\hline 12 & ZG4 & Lactobacillus plantarum strain Y-2-14 & EU637399.1 & 94 \\
\hline 13 & ZG5 & Lactobacillus plantarum strain gp112 & KM495896.1 & 100 \\
\hline
\end{tabular}

ZC indicates isolates obtained from cows' milk cheese; $\mathbf{Z C a}$ indicates isolates obtained from camels' milk cheese; $\boldsymbol{Z} \boldsymbol{G}$ indicates isolates obtained from goats' milk cheese.

\subsection{Discussion}

Lactic acid bacteria are microorganisms that produce lactic acid as a result of the fermentation of carbohydrates. They are generally regarded micro- organisms with no harmful activity Ibinabo et al., [11]. In the food and beverage industries, LABs are usually utilized as probiotic or functional starter microorganisms. Lactic acid is the main end product of carbohydrate fermentation in these starter microorganisms Smid et al.,[14]. They are widely used to process dairy and non-dairy food products such as yoghurt (Streptococcus spp and Lactobacillus spp), cheese (Lactobacillus spp and Lactococcus spp), and Sauerkraut (Leuconostoc spp) Ouattara et al., [15]. The study design was carried out to explore the 
dominance of LAB (Table 2) involved in the production of artisanal cheese in the Zinder region (Niger Republic). The study's results and findings are in line with the findings of Mulaw et al., [10] whereby they showed that most the LAB isolates belong to the genus of Lactobacillus and only 3 were found to belong to the genus of Weissella. Similar results were found by Jonathan et al.,[16] and Bansal et al.,[17]. The morphology of the LAB (Table 1) obtained in this study was in agreement with the findings reported by Husseini et al.,[18] and Ibinabo et al.,[11] where they isolated LAB from fermented vegetable amaranth. A carbohydrate utilization test using Triple Sugar Ion Agar was performed to determine whether the isolates can ferment sucrose, glucose, and galactose. All the isolated bacteria were found to be able to ferment the given carbohydrates. These findings are consistent with the research results of Husseini et al. [18]. When The isolates were put to the test and seeing if they could grow at 15 and $45^{\circ} \mathrm{C}$, it was discovered that all of them could grow at $15^{\circ} \mathrm{C}$, but only 8 could grow at $45^{\circ} \mathrm{C}$. Similar results have been previously reported by Ibinabo et al., [11]. The isolates showed their ability to grow at a salt concentration of $5 \%$ and $6.5 \% \mathrm{NaCl}$; but only 5 isolates were discovered to be growing at a $\mathrm{NaCl}$ concentration of $10 \%$. This is closely in accordance with the study of Ismail et al., [9]. The production of gas was investigated as a functioning parameter with the aim of classifying the isolates as homofermentative or heterofermentative. This categorization is useful for selecting the food matrix that would get the potentially probiotic microorganism. It was found that ten of the thirteen isolates generated gas from glucose. In contrast with da Silva et al., [19] found only one LAB isolate that generated gas from glucose. Regarding to the antibiotic susceptibility tests, this study results showed that most of the LAB isolates from "Tchoukou" were susceptible against a panel of eight antibiotics somehow. These findings corroborated previous research report of Devirgiliis et al., [20] who according to their previous laboratory report "phenotypic characterisation of tetracycline, erythromycin, and kanamycin resistance in 500 Lactic Acid Bacteria (LAB) isolated from raw materials and end products collected during the production process of a classic Italian cheese, Mozzarella Bufala Campana (MBC). Antibiotic resistant genes were almost exclusively found in bacteria isolated from raw, unprocessed substrates, whereas the final, marketed products did not contain phenotypically resistant Lactic Acid Bacteria, implying that the procedures used to make $\mathrm{MBC}$ operate as a negative selection against those components of the fermenting microflora that are most frequently found to harbour Antibiotic resistant genes".

\subsection{Conclusion}

The findings of this study revealed which strain of Lactic Acid Bacteria is present in handmade cheeses produced in Zinder region of the Republic of Niger. Lactic acid bacteria were obtained from cheese samples, morphologically and biochemically examined, and molecularly identified as Lactobacillus plantarum and Weissella cibaria. L. plantarum was found to be the most dominant LAB in these cheeses samples. Therefore, the cheeses that were sourced from camel's milk and goat's milk contain high Lactic Acid Bacteria with the good morphological and biochemical properties which could serve as the potential source for the industries and commercial applications. In this, we recommend the probiotic properties of the same isolates to be investigated in quality assurance methodologies for measuring dosage, viability, and structural and functional integrity of vital microbiome knowledge and translating it into emotional and meaningful advantages for policymakers. 


\section{Disclosure statement}

The authors report no conflicts of interest. The authors are solely responsible for the content of the manuscript.

\section{Funding}

Financial support for this research study was provided by the African Union through the Pan African Institute of Basic Sciences, Technology and Innovation, Pan African University (PAUSTI), Nairobi Kenya.

\section{Author Contributions}

Mahamadou R., M., A., conceptualization \& writing-Original Draft Preparation; Willis Owino and Kevin Mbogo: supervision \& Writing-Review\& Editing.

\section{Acknowledgements}

The authors would like to thank the Pan African University Institute for Basic Sciences, Technology, and Innovation (PAUSTI) and the Department of Food Science and Technology at Jomo Kenyatta University of Agriculture and Technology for providing all laboratory facilities and assistance throughout the project's duration. The authors are also thankful to the African Union for its financial assistance during the project's completion.

\section{References}

[1] Henchion, M., Moloney, A. P., Hyland, J., Zimmermann, J., \& McCarthy, S. (2021). Review: Trends for meat, milk and egg consumption for the next decades and the role played by livestock systems in the global production of proteins. Animal, (xxxx), 100287. https://doi.org/10.1016/j.animal.2021.100287

[2] García-Burgos, M., Moreno-Fernández, J., Alférez, M. J. M., Díaz-Castro, J., \& López-Aliaga, I. (2020). New perspectives in fermented dairy products and their health relevance. Journal of Functional Foods, 72(May), 104059. https://doi.org/10.1016/j.jff.2020.104059

[3] Santiago-lópez, L., Aguilar-toalá, J. E., Hernández-mendoza, A., Vallejo-cordoba, B., Liceaga, A. M., \& González-córdova, A. F. (2018). Invited review : Bioactive compounds produced during cheese ripening and health effects associated with aged cheese consumption. Journal of Dairy Science, 101(5), 3742-3757. https://doi.org/10.3168/jds.2017-13465

[4] Ndoye, et al. (2011). A review of the molecular approaches to investigate the diversity and activity of cheese microbiota. Dairy Science and Technology, 91(5), 495524. https://doi.org/10.1007/s13594-011-0031-8

[5] González-Martín, et al. (2020). The determination of fatty acids in cheeses of variable composition (cow, ewe's, and goat) by means of near infrared spectroscopy. Microchemical Journal, 156, 104854. https://doi.org/10.1016/j.microc.2020.104854

[6] Nilsen, R., Pripp, A. H., Høstmark, A. T., Haug, A., \& Skeie, S. (2014). Short communication: Is consumption of a cheese rich in angiotensin-converting enzymeinhibiting peptides, such as the Norwegian cheese Gamalost, associated with reduced blood pressure? Journal of Dairy Science, 97(5), 2662-2668. https://doi.org/10.3168/jds.2013-7479 
[7] Stoll, D. A., Wafula, E. N., Mathara, J. M., Trierweiler, B., Kulling, S. E., \& Huch, M. (2021). Fermentation of African nightshade leaves with lactic acid bacterial starter cultures. International Journal of Food Microbiology, 342, 109056. https://doi.org/10.1016/J.IJFOODMICRO.2021.109056

[8] Abdou AM, Hedia RH, Omara ST, Mahmoud MAEF, Kandil MM, Bakry MA (2018). Interspecies comparison of probiotics isolated from different animals. Veterinary World 11(2):227-230.

[9] Ismail, Y. S., Yulvizar, C., \& Mazhitov, B. (2018). Characterization of lactic acid bacteria from local cows milk kefir. IOP Conference Series: Earth and Environmental Science, 130(1). https://doi.org/10.1088/1755-1315/130/1/012019

[10] Mulaw G, Sisay Tessema T, Muleta D, Tesfaye A (2019). In vitro evaluation of probiotic properties of lactic acid bacteria isolated from some traditionally fermented ethiopian food products. International Journal of Microbiology https://doi.org/10.1155/2019/7179514

[11] Ibinabo, T. I., Eliud, N. W., Josiah, K., \& Julius, M. M. (2021). Phenotypic and genotypic characterization of lactic acid bacteria isolated from spontaneously fermented vegetable amaranth. African Journal of Food Science, 15(6), 254-261. https://doi.org/10.5897/ajfs2021.2107

[12] Tamura K. and Nei M. (1993). Estimation of the number of nucleotide substitutions in the control region of mitochondrial DNA in humans and chimpanzees. Molecular Biology and Evolution 10:512-526.

[13] Kumar S., Stecher G., Li M., Knyaz C., and Tamura K. (2018). MEGA X: Molecular Evolutionary Genetics Analysis across computing platforms. Molecular Biology and Evolution 35:1547-1549.

[14] Smid, E. J., Erkus, O., Spus, M., Wolkers-Rooijackers, J. C. M., Alexeeva, S., \& Kleerebezem, M. (2014). Functional implications of the microbial community structure of undefined mesophilic starter cultures. Microbial Cell Factories, 13(1), 1-9. https://doi.org/10.1186/1475-2859-13-S1-S2

[15] Ouattara, D. H., Ouattara, H. G., Goualie, B. G., Kouame, L. M., \& Niamke, S. L. (2014). Biochemical and functional properties of lactic acid bacteria isolated from Ivorian cocoa fermenting beans. Journal of Applied Biosciences, 77(1), 6489. https://doi.org/10.4314/jab.v77i1.9

[16] Gebhart, C. (2014). Molecular Microbiology: Diagnostic Principles and Practice, 2 nd edition . In Laboratory Medicine (Vol. 45). https://doi.org/10.1309/lmbw4ekpg1 tmctyo

[17] Bansal, S., Singh, A., Mangal, M., \& Sharma, S. K. (2013). Isolation and characterization of lactic acid bacteria from fermented foods. Vegetos, 26(2), 325-330. https://doi.org/10.5958/j.2229-4473.26.2.092

[18] Hussaini, I. M. e. al. (2020). Assessment of the Probiotic Potential of Lactobacillus species Isolated from Selected Brands of Yoghurt sold in Zaria, Kaduna State, Nigeria. 34(2), 5360-5367.

[19] da Silva, L. A., Lopes Neto, J. H. P., \& Cardarelli, H. R. (2019). Safety and probiotic functionality of isolated goat milk lactic acid bacteria. Annals of Microbiology, 
International Journal of Food Sciences

2789-7680 (online)

Vol. 4, Issue 1, No. 3, pp 30 - 41, 2021

69(13), 1497-1505. https://doi.org/10.1007/s13213-019-01533-z

[20] Devirgiliis, C., Zinno, P., \& Perozzi, G. (2013). Update on antibiotic resistance in foodborne Lactobacillus and Lactococcus species. Frontiers in Microbiology, 4(OCT), 113. https://doi.org/10.3389/fmicb.2013.00301 